\title{
A review on the solar applications of thermosyphons
}

\author{
Mahdi Ramezanizadeh ${ }^{1 *}$, Mohammad Alhuyi Nazari ${ }^{1}$, Mohammad Hossein Ahmadi $^{2}$, Giulio Lorenzini ${ }^{3}$, Ravinder Kumar ${ }^{4}$, \\ Ravindra Jilte ${ }^{4}$ \\ ${ }^{1}$ Aerospace Engineering Department, Shahid Sattari Aeronautical University of Science and Technology, Tehran, Iran \\ ${ }^{2}$ Faculty of Mechanical of engineering, Shahrood University of Technology, Shahrood, Iran \\ ${ }^{3}$ Università degli Studi di Parma, Dipartimento di Ingegneria e Architettura, Parma 43124, Italy \\ ${ }^{4}$ Department of Mechanical Engineering, Lovely Professional University, Phagwara-144411 Punjab, India
}

Corresponding Authors Email: mohammadhosein.ahmadi@gmail.com

https://doi.org/10.18280/mmep.050401

Received: 12 June 2018

Accepted: 5 September 2018

\section{Keywords:}

thermosyphon, nanofluids, solar energy systems, heat transfer, solar desalination

\begin{abstract}
Thermosyphons are used in various energy systems due to their efficient performance in heat transfer. These devices can be employed in several solar energy systems because of their high effective thermal conductivity. The most important solar applications can be listed as PV cooling, desalination units, water heating systems and thermoelectric. In the current study, the mentioned applications and the key findings of the related researches are reviewed and represented. Based on the reviewed publications, the thermal specifications of the thermosyphons affect the overall performance of the systems assisted with thermosyphons. For instance, by using nanofluids, the thermal performance of these devices improves which results in higher efficiency of the systems. Using novel ideas such as using wick in the evaporator section is another approach to achieve more proper performance of the thermosyphons in solar energy systems.
\end{abstract}

\section{INTRODUCTION}

Thermosyphons are efficient thermal mediums which are broadly employed in various energy systems such as ventilation, heat exchangers and etc. [1-4]. The performance and heat transfer ability of these devices depend on various factors. Operating fluid, inclination angle, filling ratio and heat input are among the most important effective parameters [5-7]. The main reason of heat transfer in thermosyphons is evaporation in heat source and condensation in heat sink [8]. A schematic of thermosyphon is depicted in Figure 1.

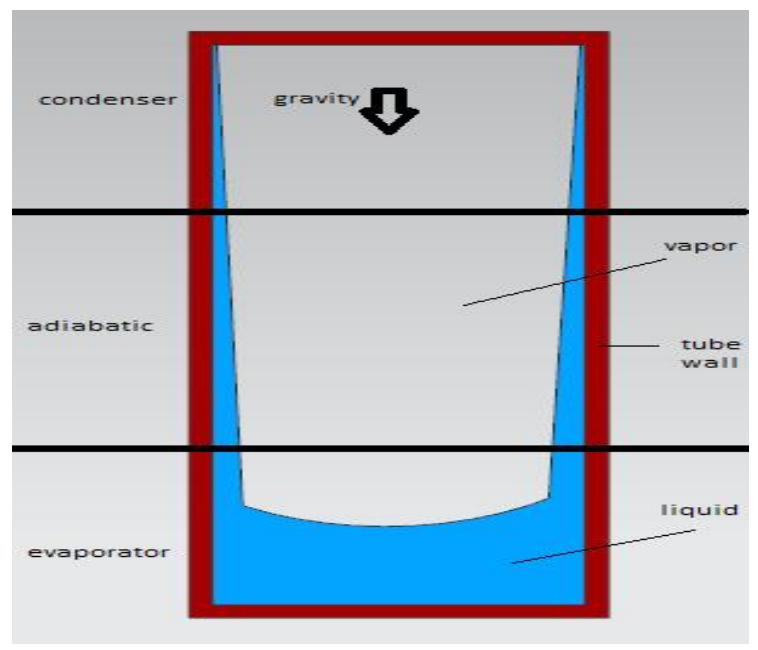

Figure 1. Schematic of thermosyphon
As it was mentioned, working fluid plays key role in the thermal behavior of thermosyphons [9-10]. Using nanofluids, due to their high thermal conductivity [11-12], is a conventional approach which is suggested by several researchers. Employing nanofluids can lead to augment in thermal performance of various kind of heat pipes [13-15]. In addition to the operating fluid, its charging ratio is another influential factor [16]. The optimum charging ratio differs for various case studies and obtained experimentally. Since the gravity causes fluid motion inside thermosyphon, most of the studies concluded that the best thermal performance is achievable near vertical orientation. In addition to the mentioned factors, heat input, due to two-phase heat transfer of thermosyphons, affects thermal resistance of the thermosyphons. Increase in heat input, enhances boiling heat transfer; however, at very high heat loads, the dry-out phenomenon occurs due to lack of liquid in evaporator.

Renewable energy sources have several environmental advantages compared with fossil fuels [17-20]. Among various renewable sources, solar energy gains importance due to its availability and high intensity. Solar energy is applicable for several purposes including heat exchangers [21], desalinating water [22], heating [23-26] and power generation [27]. Power generation can be achieved by using PV panels or extracting thermal energy of the sun to run thermodynamic cycles such as Brayton or Brayton-Rankine [28-29]. For desalination systems, the generated electricity via solar energy can be applied in reverse-osmosis systems. In addition, solar thermal energy can be used in other types of desalination units such as humidification-dehumidification types. 
In order to efficiently use solar thermal energy, it is necessary to apply thermal devices with appropriate heat transfer ability. Thermosyphons are favorable candidates to be employed in the systems require efficient heat transfer. These types of heat pipes are used in various solar-based technologies in recent years. In the current studies, the applications of thermosyphons in solar energy systems are reviewed and their findings are represented.

\section{APPLICATIONS OF THERMOSYPHONS IN SOLAR ENERGY SYSTEMS}

There are several researches concentrated on the applications of thermal mediums in solar energy technologies. The aim of the current study is representing the use of thermosyphons in these systems. In the following subsections, the most attracting applications of thermosyphons in solar energy are reviewed.

\subsection{PV cooling}

P Photovoltaic (PV) panels are employed to produce electricity from solar irradiations [30,31]. Various parameters effect on their efficiency such as tilt angle, irradiation intensity and working temperature [32-35]. Studies have shown that increase in solar cell temperature causes reduction in efficiency [36]. Finding appropriate methods to cool down the PV panels results in efficiency enhancement. PV/T systems are among the most conventional approaches used for PV cooling [37]. In these configurations, a cooling fluid is applied to cool down the cell. In addition to using cooling channels at the back of PV modules, using cooling devices such as heat pipes is an efficient approach to prevent efficiency reduction due to temperature increase. Akbarzadeh et al. [38] suggested a PV/T system which was a combination of solar concentrator system and PV panel. The schematic of the system is shown in Figure 2. In order to assess the influence of cooling system on the performance, the tests were performed by the cooling apparatus with and without fluid. The results revealed that without using the fluid, the output power of the cell had 50\% reduction compared with utilizing the cooling system. It was concluded applying thermosyphon is an influential approach to cool down the PV panel.

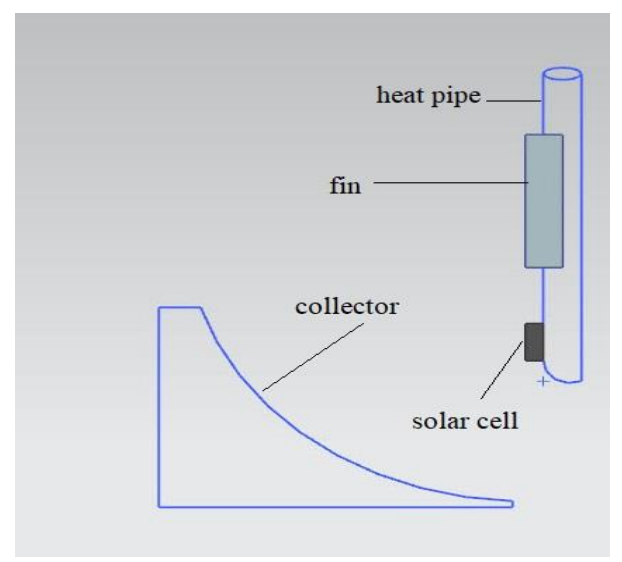

Figure 2. Schematic of PV/T system with thermosyphon [38]

Another configuration for PV/T system with an array of thermosyphons was experimentally evaluated by Moradgholi et al. [39]. 16 thermosyphons were applied for cooling the $\mathrm{PV}$ and the total area of the cell was equal to $0.003 \mathrm{~m}^{2}$. The applied thermosyphons was made of aluminum and $\mathrm{Al}_{2} \mathrm{O}_{3}$ /methanol and methanol used as operating fluids. Results indicated that using thermosyphon led to lower operating temperature of PV panel. In addition, it was observed that by using methanol as working fluid, the electrical efficiency of the $\mathrm{PV} / \mathrm{T}$ system was $0.7 \%$ higher compared with PV panel without cooling mediums, while using nanofluid resulted in $1 \%$ higher efficiency. Increases in the energy efficiency of the systems for the systems used methanol and the nanofluid were $15.3 \%$ and $27.3 \%$, respectively.

\subsection{Solar desalination}

Typically, desalination systems require thermal energy or electricity for fresh water production $[40,41]$. Both of these two types of energy can be provided by applying solar radiation [42]. There are various types of desalination systems including Reverse-Osmosis (RO), humidificationdehumidification $(\mathrm{HDH})$ and etc $[43,44]$. Behnam et al. [45] experimentally investigated a thermosyphon-assisted $\mathrm{HDH}$ desalination. The desalination system consisted of air humidifier, thermosyphon, dehumidifier, and evacuated tube collector. The thermosyphons were used to transfer absorbed heat by the collector to heat up the water. The evaporator section of the thermosyphon was located at the center of collectors and its condenser was in humidifier. The transferred heat by the thermosyphon caused boiling in humidifier section. Results showed that by using oil between the collector and thermosyphons, up to $65 \%$ efficiency for the system was achievable which indicated appropriate performance of the thermosyphons.

Faegh et al. [46] designed a novel solar desalination system by using Phase Change Material (PCM) and thermosyphon. In this system, solar energy used for evaporating the water during daytime. The PCM was applied as energy storage unit and charged by heat transfer with vaporized water. Heat transfer between the vaporized water and PCM resulted in vapor condensation and energy absorption by PCM. In the evening, the stored energy by the PCM transferred to the saline water, via thermosyphon, to produce fresh water. Comparing the performance of the systems with and without PCM showed $86 \%$ increase in efficiency in the case of applying PCM.

\subsection{Water heating systems}

The solar energy can be employed to provide hot water for facilities and buildings without consumption fossil fuels [4749]. These types of water heating systems can be coupled with storage tanks to be applicable during night-time [50]. Thermosyphons are appropriate devices for transferring the absorbed thermal energy of sun to warm up water [51-52]; in addition, thermosyphons can be used in the heat exchangers applied in water heating systems [53]. The performance of the solar water heater depends on several factors such as temperature of cold water, quality of manufacturing and design specifications [54-55]. In the thermosyphon-assisted water heating systems, the evaporator section of the thermosyphon located in solar collector. By receiving the solar thermal energy, the working fluid inside the thermosyphon evaporates and moves to condenser section 
which is water storage tank [56]. Heat transfer between condenser section of thermosyphon and content of the storage tank results in condensation of vapor. The vapor returns to the evaporator part and this process continues. Since the performance of the thermosyphon depends on its working fluid, changing the operating fluid affects the overall efficiency of the system. Based on a study carried out by Esen et al. [56], three operating fluids including R410a, R407C and R-134a were used in the thermosyphon of the system shown in Error! Reference source not found. Results demonstrated that using R410a led to the maximum efficiency of the system among the tested fluids. The highest daily collecting efficiency of the system filed with R410a was $58.96 \%$.

Since the thermal performance of thermosyphon in water heating systems influences on the efficiency of these technologies, enhancement in the heat transfer capability of thermosyphons results in performance improvement. Huang et al. [57] investigated the effect of filling ratio and evaporator structure on the performance of two-phase closed loop thermosyphon used in solar water heater. The filling ratio of the thermosyphon was methanol. Two filling ratios including $40 \%$ and $60 \%$ were considered in the study to analyze the effect of charging rate. In addition to conventional structure, in another thermosyphon a porous wick was inserted in the evaporator part. Obtained results revealed that using the wick in evaporator led to $12.7 \%$ efficiency enhancement of the system. Moreover, it was concluded that at high heat inputs, $60 \%$ filling ratio resulted in better performance in comparison with $40 \%$. The effect of filling ratio on the performance of water heating system with thermosyphon was investigated in another study performed by Zhang et al. [58]. In their research, the operating fluid was R600a and five filling ratios including 10\%, 20\%, 30\% and $50 \%$ were evaluated to obtain the best condition. Results revealed the highest efficiency was achievable in the filling ratio between $30 \%$ and $50 \%$.

In another research, a novel configuration of heating system introduced by Velmurugan et al. [59] which was used for heating air and water by employing thermosyphon as thermal medium. In the proposed configuration, three circuits were used to circulate heat carrying fluid, fluid and air used for consumer utilization. The performance of the system was evaluated under two modes for water and air heating. Based on the results, the maximum efficiencies of the system for water and air heating were $73.68 \%$ and $69.18 \%$ respectively.

\subsection{Solar thermoelectric systems}

The thermal energy of sun is applicable in thermoelectric to obtain electricity [60-61]. A configuration integrated with thermosyphon was introduced by Miljkovic et al. [62] to passively transfer the thermal energy to another cycle in order to utilize it for various purposes. In this configuration, the evaporator section of thermosyphon was connected to the cold side of the thermosyphon. Due to temperature gradient between two sides of the thermoelectric, the electricity was generated. In addition, the thermosyphon was applied to axially transfer heat from cold side of the thermoelectric. Based on the results of modeling, the performance of the system was dependent on several factors such as temperature of bottoming cycle (thermosyphon condenser) and solar irradiation. It was concluded that increase in solar concentration led to improvement in both thermal and electrical efficiencies.

In another study [63], a thermosyphon and thermoelectric module were applied in a solar pond to generate electricity. In the proposed system, the thermosyphon was employed in order to transfer heat from hot part to the cold part of the solar pond. The thermoelectric module was connected to the top section of the thermosyphon which was located at the upper convective zone. The schematic of the introduced system is shown in Figure 3. The dimeter and length of the thermosyphon were $100 \mathrm{~mm}$ and $2 \mathrm{~m}$, respectively. 16 thermoelectric cells with $40 \times 40 \times 3.9 \mathrm{~mm}$ dimensions were used in this configuration. Results revealed that by using the configuration, it is possible to passively produce electricity with solar ponds. The maximum generated power by this system was $3.2 \mathrm{~W}$ which shows its efficient performance.

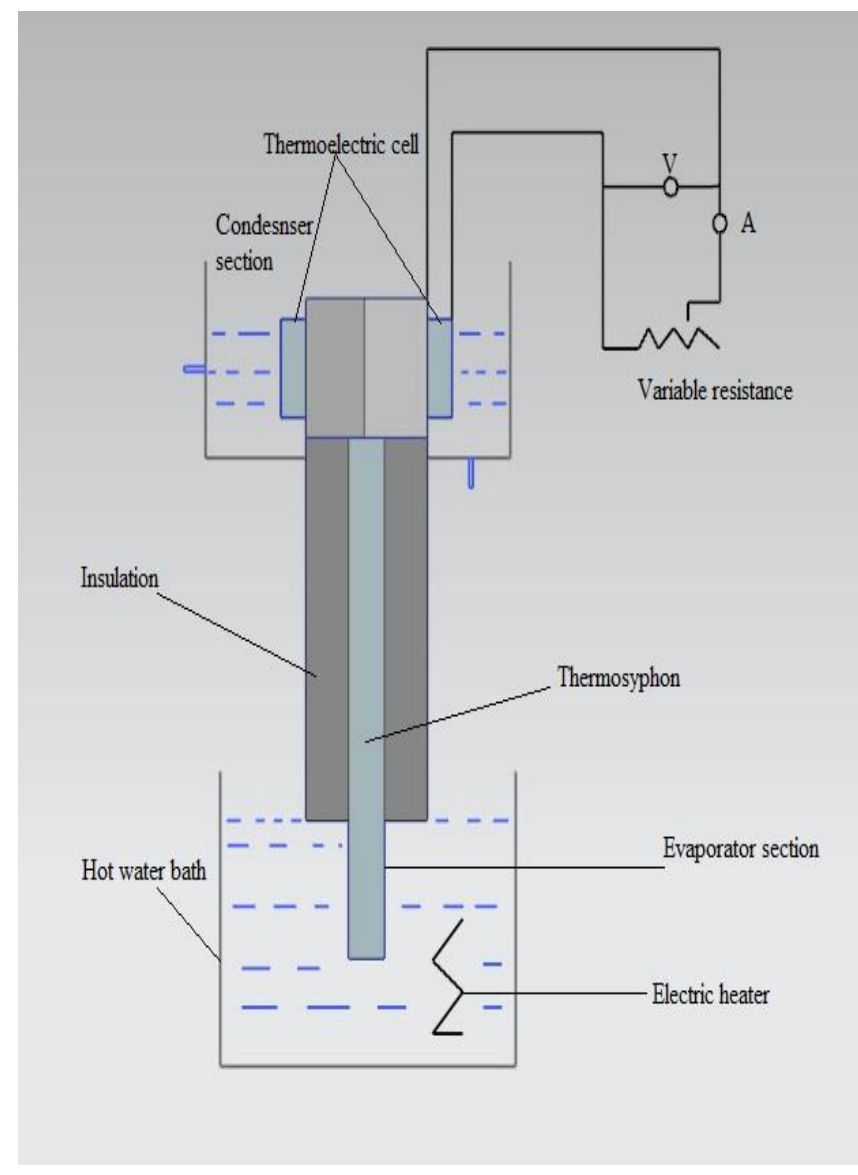

Figure 3. Schematic of the solar pond with thermosyphon and thermoelectric

\subsection{Solar collectors}

Thermosyphons can be employed in solar collectors in order to have efficient heat transfer. The performance of the thermosyphon-assisted solar collectors is dependent on the thermal behavior of the thermosyphon which is affected by working fluid, inclination angle and etc. According to the various studies [64-65], by using nano-sized materials, the efficiency of the systems can be enhanced. Chougule et al. [66] evaluated the performance of a two-phase thermosyphon applied in solar collector. In their study, pure water and $\mathrm{CNT} /$ water nanofluid in four volumetric concentrations including $0.15 \%, 0.45 \%, 0.60 \%$ and $1 \%$ were employed as operating fluid of the thermosyphon. Moreover, the five tilt 
angles $(20,32,40,50$ and $60 \mathrm{deg})$ were tested to investigate the thermal performance. It was observed that utilizing the nanofluid led to enhancement of the efficiency of the system. The average efficiency of the collector in various concentrations of the nanofluid is represented in Figure 4.

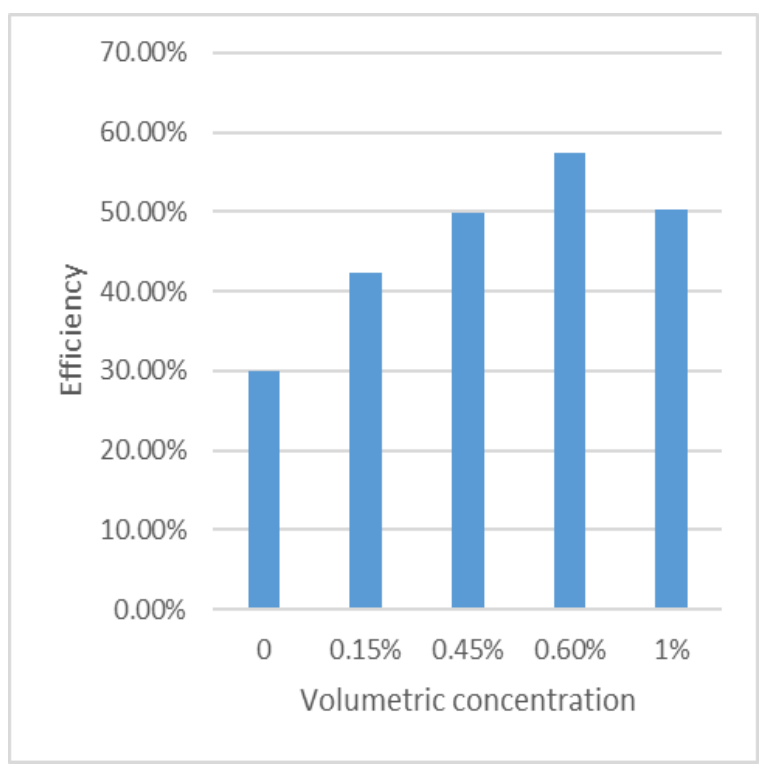

Figure 4. Effect of volumetric concentration on the efficiency of solar collector

As shown in Figure, there was an optimum value for the concentration in order to achieve the highest efficiency. In addition, it was found that for the system with water as thermosyphon operating fluid, the maximum efficiency obtained in $50 \mathrm{deg}$.

\section{CONCLUSIONS}

In the present review article, a comprehensive review is conducted on the solar applications of thermosyphons. It is found that thermosyphons can be employed in various solar energy systems as thermal medium in order to have efficient and reliable heat transfer. The most conventional applications of thermosyphons in solar systems are desalination, water heaters, collectors and PV cooling. Based on the results of the reviewed studies, improving the thermal performance of the thermosyphons leads to augment in overall efficiency of the systems. Using nanofluids, novel structures such as inserting wick in the evaporator section and working on optimum filling ratio and tilt angle are among the most applicable approaches to reach the highest efficiency. Future researches can be performed on other related applications of thermosyphons. Moreover, investigating other factors such as working conditions, hybrid fluids and material of the thermosyphons affecting thermal performance and their influences on the efficiency of the systems will be the aims of future studies.

\section{REFERENCES}

[1] Filippeschi S, Latrofa E, Salvadori G. (2006). Periodic two-phase heat transfer coefficient in thermoelectric cooling mini evaporator. Int J Low-Carbon Technol 1:
298-314. https://doi.org/10.1093/ijlct/1.4.298

[2] Arias FJ. (2018). A first estimate for a pressure retarded osmosis-driven thermosyphon. Sol Energy 159: 962-5. https://doi.org/10.1016/J.SOLENER.2017.10.064

[3] Filippeschi S, Su Y, Riffat SB. (2013). Feasibility of periodic thermosyphons for environmentally friendly ground source cooling applications. Int $\mathbf{J}$ Low-Carbon Technol 8: 117-23. https://doi.org/10.1093/ijlct/cts002.

[4] Ong KS. (2016). Review of heat pipe heat exchangers for enhanced dehumidification and cooling in air conditioning systems. Int $\mathbf{J}$ Low-Carbon Technol 11: 416-23. https://doi.org/10.1093/ijlct/ctu029

[5] Jafari D, Franco A, Filippeschi S, Di Marco P. (2016). Two-phase closed thermosyphons: A review of studies and solar applications. Renew Sustain Energy Rev 53: 575-93. https://doi.org/10.1016/J.RSER.2015.09.002

[6] Zhang H, Shi Z, Liu K, Shao S, Jin T, Tian C. (2017). Experimental and numerical investigation on a $\mathrm{CO}_{2}$ loop thermosyphon for free cooling of data centers. Appl Therm Eng 111: 1083-90. https://doi.org/10.1016/j.applthermaleng.2016.10.029

[7] Xu Z, Zhang Y, Li B, Wang CC, Li Y. (2018). The influences of the inclination angle and evaporator wettability on the heat performance of a thermosyphon by simulation and experiment. Int $\mathbf{J}$ Heat Mass Transf 116: 675-84. https://doi.org/10.1016/J.IJHEATMASSTRANSFER.20 17.09.028

[8] Reay DA. (2015). Thermal energy storage: the role of the heat pipe in performance enhancement. Int J LowCarbon Technol 10: 99-109. https://doi.org/10.1093/ijlct/ctv009

[9] Shanbedi M, Heris SZ, Baniadam M, Amiri A, Maghrebi M. (2012). Investigation of Heat-Transfer Characterization of EDA-MWCNT/DI-Water Nanofluid in a Two-Phase Closed Thermosyphon. Ind Eng Chem Res 51: 1423-8. https://doi.org/10.1021/ie202110g

[10] Salehi H, Zeinali Heris S, Sharifi F, Razbani MA. (2013). Effects of a nanofluid and magnetic field on the thermal efficiency of a two-phase closed thermosyphon. Heat Transf Res 42: 630-50. https://doi.org/10.1002/htj.21043

[11] Ahmadi MH, Mirlohi A, Nazari MA, Ghasempour R. (2018). A review of thermal conductivity of various nanofluids. $\quad \mathrm{J} \quad \mathrm{Mol} \quad \mathrm{Liq}$ https://doi.org/10.1016/j.molliq.2018.05.124

[12] Ramezanizadeh M, Alhuyi Nazari M, Ahmadi MH, Açıkkalp E. (2018). Application of nanofluids in thermosyphons: A review. J Mol Liq 272. https://doi.org/10.1016/j.molliq.2018.09.101

[13] Alhuyi NM, Ahmadi MH, Ghasempour R, Shafii MB. (2018). How to improve the thermal performance of pulsating heat pipes: A review on working fluid. Renew Sustain Energy Rev 91: 630-8.

[14] Nazari MA, Ghasempour R, Ahmadi MH, Heydarian G, Shafii MB. (2018). Experimental investigation of graphene oxide nanofluid on heat transfer enhancement of pulsating heat pipe. Int Commun Heat Mass Transf 91:

$90-4$. https://doi.org/10.1016/j.icheatmasstransfer.2017.12.00 6

[15] Gandomkar A, Saidi MH, Shafii MB, Vandadi M, Kalan K. (2017). Visualization and comparative investigations of pulsating ferro-fluid heat pipe. Appl 
Therm

Eng

116:

56-65.

https://doi.org/10.1016/j.applthermaleng.2017.01.068

[16] Noie SH, Sarmasti Emami MR, Khoshnoodi M. (2007). Effect of inclination angle and filling ratio on thermal performance of a two-phase closed thermosyphon under normal operating conditions. Heat Transf Eng 28: 36571. https://doi.org/10.1080/01457630601122997

[17] Amin TE, Roghayeh G, Fatemeh R, Fatollah P. (2015). Evaluation of nanoparticle shape effect on a nanofluid based flat-plate solar collector efficiency. Energy Explor Exploit 33: 659-76. https://doi.org/10.1260/0144-5987.33.5.659

[18] Narei H, Ghasempour R, Noorollahi Y. (2016). The effect of employing nanofluid on reducing the bore length of a vertical ground-source heat pump. Energy Convers Manag 123: 581-91. https://doi.org/10.1016/j.enconman.2016.06.079

[19] Rezaei MH, Sadeghzadeh M, Alhuyi Nazari M, Ahmadi MH, Astaraei FR. (2018). Applying GMDH artificial neural network in modeling $\mathrm{CO}_{2}$ emissions in four nordic countries. Int $\mathrm{J}$ Low-Carbon Technol. https://doi.org/10.1093/ijlct/cty026

[20] Cascetta F, Cirillo L, Della Corte A, Nardini S. (2017). Comparison between different solar cooling thermally driven system solutions for an office building in Mediterranean Area. Int J Heat Technol 35: 130-8. https://doi.org/10.18280/ijht.350118

[21] Zhang H, Shao S, Tian C, Zhang K. (2018). A review on thermosyphon and its integrated system with vapor compression for free cooling of data centers. Renew Sustain Energy Rev 81: 789-98. https://doi.org/10.1016/J.RSER.2017.08.011

[22] Nazari MA, Ahmadi MH, Ghasempour R. (2018). A review on pulsating heat pipes : From solar to cryogenic applications 222: 475-84. https://doi.org/10.1016/j.apenergy.2018.04.020

[23] Arab M, Soltanieh M, Shafii MB. (2012). Experimental investigation of extra-long pulsating heat pipe application in solar water heaters. Exp Therm Fluid Sci 42:

$6-15$.

https://doi.org/10.1016/J.EXPTHERMFLUSCI.2012.03 .006

[24] Den Braven KR. (1989). Two-phase heat transfer in thermosyphon evacuated-tube solar collectors. J Sol Energy Eng 111: 292. https://doi.org/10.1115/1.3268324

[25] Haghighi Bardineh Y, Mohamadian F, Ahmadi MH, Akbarianrad N. (2018). Medical and dental applications of renewable energy systems. Int $\mathbf{J}$ Low-Carbon Technol. https://doi.org/10.1093/ijlct/cty040

[26] Ghritlahre HK, Prasad RK. (2018). Investigation on heat transfer characteristics of roughened solar air heater using ANN technique. Int $\mathrm{J}$ Heat Technol 36: $102-10$.

[27] Alhuyi Nazari M, Aslani A, Ghasempour R. (2018). Analysis of solar farm site selection based on TOPSIS approach. Int J Soc Ecol Sustain Dev 9.

[28] Alizadeh H, Ghasempour R, Shafii MB, Ahmadi MH, Yan WM, Nazari MA. (2018). Numerical simulation of PV cooling by using single turn pulsating heat pipe. Int J Heat Mass Transf 127: 203-8. https://doi.org/10.1016/J.IJHEATMASSTRANSFER.20 18.06.108
[29] Ahmadi MH, Ahmadi MA, Feidt M. (2016). Performance optimization of a solar-driven multi-step irreversible brayton cycle based on a multi-objective genetic algorithm. Oil Gas Sci Technol - Rev d'IFP Energies Nouv 71: 16. https://doi.org/10.2516/ogst/2014028

[30] Sooriyaarachchi TM, Tsai IT, El Khatib S, Farid AM, Mezher T. (2015). Job creation potentials and skill requirements in, $\mathrm{PV}, \mathrm{CSP}$, wind, water-to-energy and energy efficiency value chains. Renew Sustain Energy Rev 52: 653-68. https://doi.org/10.1016/J.RSER.2015.07.143

[31] Dağtekin M, Kaya D, Öztürk HH, Kiliç FÇ. (2014). A study of techno-economic feasibility analysis of solar photovoltaic $(\mathrm{pv})$ power generation in the province of adana in turkey. Energy Explor Exploit 32: 719-35. https://doi.org/10.1260/0144-5987.32.4.719

[32] Ibrahim H, Anani N. (2017). Variations of PV module parameters with irradiance and temperature. Energy Procedia 134: 276-85. https://doi.org/10.1016/J.EGYPRO.2017.09.617

[33] Schwingshackl C, Petitta M, Wagner JE, Belluardo G, Moser D, Castelli M, et al. (2013). Wind effect on PV module temperature: Analysis of different techniques for an accurate estimation. Energy Procedia 40: 77-86. https://doi.org/10.1016/J.EGYPRO.2013.08.010

[34] Kemme P, Zeiler W. (2017). Influence effect of energy roof on PV efficiency: A case study. mediterr. green build. Renew. Energy, Cham: Springer International Publishing 61-72. https://doi.org/10.1007/978-3-31930746-6_5

[35] Bahaidarah H, Rehman S, Subhan A, Gandhidasan P, Baig H. (2015). Performance evaluation of a PV module under climatic conditions of dhahran, saudi arabia. Energy Explor Exploit 33: 909-29. https://doi.org/10.1260/0144-5987.33.6.909

[36] Alizadeh H, Ghasempour R, Razi Astaraei F, Alhuyi Nazari M. (2016). Numerical modeling of PV cooling by using pulsating heat pipe. 3rd Int. Conf. Exhib. Sol. Energy ICESE-2016, Tehran.

[37] Preet S, Bhushan B, Mahajan T. (2017). Experimental investigation of water based photovoltaic/thermal (PV/T) system with and without phase change material (PCM). Sol Energy 155: 1104-20. https://doi.org/10.1016/j.solener.2017.07.040

[38] Akbarzadeh A, Wadowski T. (1996). Heat pipe-based cooling systems for photovoltaic cells under concentrated solar radiation. Appl Therm Eng 16: 81-7. https://doi.org/10.1016/1359-4311(95)00012-3

[39] Moradgholi M, Mostafa Nowee S, Farzaneh A. (2018). Experimental study of using Al2O3/methanol nanofluid in a two phase closed thermosyphon (TPCT) array as a novel photovoltaic/thermal system. Sol Energy 164: 243-50. https://doi.org/10.1016/J.SOLENER.2018.02.055

[40] Charcosset C. (2009). A review of membrane processes and renewable energies for desalination. Desalination 245: 214-31. https://doi.org/10.1016/J.DESAL.2008.06.020

[41] AlMadani HMN. (2003). Water desalination by solar powered electrodialysis process. Renew Energy 28: 1915-24. 1481(03)00014-4 
[42] Salam MA, Khan SA. (2018). Transition towards sustainable energy production - A review of the progress for solar energy in saudi arabia. Energy Explor Exploit 36: 3-27. https://doi.org/10.1177/0144598717737442

[43] Romero-Ternero V, García-Rodríguez L, GómezCamacho C. (2005). Thermoeconomic analysis of a seawater reverse osmosis plant. Desalination 181: 4359. https://doi.org/10.1016/J.DESAL.2005.02.012

[44] Kabeel AE, El-Said EMS. (2013). A hybrid solar desalination system of air humidificationdehumidification and water flashing evaporation: Part I. A numerical investigation. Desalination 320: 56-72. https://doi.org/10.1016/J.DESAL.2013.04.016

[45] Behnam P, Shafii MB. (2016). Examination of a solar desalination system equipped with an air bubble column humidifier, evacuated tube collectors and thermosyphon heat pipes. Desalination 397: 30-7. https://doi.org/10.1016/J.DESAL.2016.06.016

[46] Faegh M, Shafii MB. (2017). Experimental investigation of a solar still equipped with an external heat storage system using phase change materials and heat pipes. Desalination 409: 128-35. https://doi.org/10.1016/j.desal.2017.01.023

[47] Huang BJ. (1993). Performance rating method of thermosyphon solar water heaters. Sol Energy 50: 43540. doi:10.1016/0038-092X(93)90065-V

[48] Malkin MP, Klein SA, Duffie JA, Copsey AB. (1987). A design method for thermosyphon solar domestic hot water systems. J Sol Energy Eng 109: 150. https://doi.org/10.1115/1.3268192

[49] Benhouia AT, Teggar M, Benchatti A. (2018). Effect of sand as thermal damper integrated in flat plate water solar thermal collector. Int J Heat Technol 36: 21-5. https://doi.org/10.18280/ijht.360103

[50] Nwosu PN, Oparaku OU, Okonkwo WI, Unachukwu GO, Agbiogwu D. (2011). Experimental study of a thermosyphon solar water heater coupled to a fibrereinforced plastic (FRP) storage tank. Appl Sol Energy 47: 207-12. https://doi.org/10.3103/S0003701X11030157

[51] Belessiotis V, Mathioulakis E. (2002). Analytical approach of thermosyphon solar domestic hot water system performance. Sol Energy 72: 307-15. https://doi.org/10.1016/S0038-092X(02)00011-7

[52] Carbonell D, Cadafalch J, Consul R. (2013). Dynamic modelling of flat plate solar collectors. Analysis and validation under thermosyphon conditions. Sol Energy 89:

$100-12$

https://doi.org/10.1016/J.SOLENER.2012.12.014

[53] Dahl SD, Davidson JH. (1997). Performance and modeling of thermosyphon heat exchangers for solar water heaters. J Sol Energy Eng 119: 193 https://doi.org/10.1115/1.2888018

[54] Jiang QY, He W, Hou JX, Ji J. (2010). A new performance evaluation method for solar thermosyphon systems. Int J Low-Carbon Technol 5: 239-44. https://doi.org/10.1093/ijlct/ctq029

[55] Joshi SV, Bokil RS, Nayak JK. (2005). Test standards for thermosyphon-type solar domestic hot water system: Review and experimental evaluation. Sol Energy 78: 781-98. https://doi.org/10.1016/J.SOLENER.2004.08.023

[56] Esen M, Esen H. (2005). Experimental investigation of a two-phase closed thermosyphon solar water heater. Sol Energy 79: 459-68. https://doi.org/10.1016/J.SOLENER.2005.01.001

[57] Huang C, Lin WK, Wang SR. (2017). Two-phase closed-loop thermosyphon solar water heater with porous wick structure: Performance and start-up time. Arab J Sci Eng 42: 4885-94. https://doi.org/10.1007/s13369-017-2660-6.

[58] Zhang T, Pei G, Zhu Q, Ji J. (2016). Investigation on the optimum volume-filling ratio of a loop thermosyphon solar water-heating system. J Sol Energy Eng 138: 041006. https://doi.org/10.1115/1.4033403

[59] Velmurugan K, Christraj W, Kulasekharan N, Elango T. (2016). Performance study of a dual-function thermosyphon solar heating system. Arab J Sci Eng 41: 1835-46. https://doi.org/10.1007/s13369-015-1994-1

[60] Atik K. (2009). Thermoeconomic optimization in the design of thermoelectric cooler. Proc. 5th Int. Adv. Technol. Symp 13-5.

[61] Hu X, Jood P, Ohta M, Kunii M, Nagase K, Nishiate H, et al. (2016). Power generation from nanostructured PbTe-based thermoelectrics: Comprehensive development from materials to modules. Energy Environ Sci 9: 517-29. https://doi.org/10.1039/c5ee02979a

[62] Miljkovic N, Wang EN. (2011). Modeling and optimization of hybrid solar thermoelectric systems with thermosyphons. Sol Energy 85: 2843-55. https://doi.org/10.1016/J.SOLENER.2011.08.021

[63] Singh R, Tundee S, Akbarzadeh A. (2011). Electric power generation from solar pond using combined thermosyphon and thermoelectric modules. Sol Energy 85:

371-8.

https://doi.org/10.1016/J.SOLENER.2010.11.012

[64] Mohamadian F, Eftekhar L, Haghighi Bardineh Y. (2018). Applying GMDH artificial neural network to predict dynamic viscosity of an antimicrobial nanofluid. Nanomedicine J 5 : 217-21. https://doi.org/10.22038/NMJ.2018.05.00005

[65] Akbarianrad N, Mohammadian F, Alhuyi Nazari M, Rahbani Nobar B. (2018). Applications of nanotechnology in endodontic: A review. Nanomedicine $\quad J \quad$ 5: https://doi.org/10.22038/NMJ.2018.005.0001

[66] Chougule SS, Pradesh M. (2016). Thermal performance of two phase thermosyphon flat-plate solar collectors using nanofluid 136: 1-5. https://doi.org/10.1115/1.4025591 